\title{
NEW THIOPHENE BEARING DIMETHYL-5-HYDROXY ISOPHTALATE ESTERS AND THEIR ANTIMICROBIAL ACTIVITIES
}

\author{
Hakan ÜNVER ${ }^{1, *}$, Zerrin CANTÜRK \\ ${ }^{1}$ Chemistry Department, Faculty of Science, Anadolu University, 26470, Eskişehir, Turkey \\ ${ }^{2}$ Pharmaceutcal Microbiology, Faculty of Pharmacy, Anadolu University, 26470, Eskişehir, Turkey
}

\begin{abstract}
Thiophene belongs to a class of heterocyclic compounds. In this study, three new dimethyl-5-hydroxy isophtalate derived thiophene esters were successfully synthesized and characterized by FT-IR, Elementel Analysis, ${ }^{1} \mathrm{H}-\mathrm{NMR},{ }^{13} \mathrm{C}-\mathrm{NMR}$ and $\mathrm{HR}-$ Mass techniques. Synthesized compounds antimicrobial effects were tested on Staphylococcus aureus (ATCC 25923); Enterococcus faecalis (ATCC 29212); Enterococcus faecalis (ATCC 51922); Klebsiella pneumoniae (ATCC 700603); Pseudomonas aeruginosa (ATCC 27853); Escherichia coli (ATCC 35218); Escherichia coli (ATCC 25922) and Candida albicans (ATCC 90028); Candida glabrata (ATCC 90030); Candida krusei (ATCC 6258); Candida parapsilosis (ATCC 22019). Compound $\mathbf{C}_{1}$ showed the highest antimicrobial activity, possessing the same potential as chloramphenicol against, $P$. aeruginosa ATCC 27853. According to MTT assays, this compound $\left(\mathbf{C}_{1}\right)$ was identified as non-toxic.
\end{abstract}

Keywords: Thiophene, Antibacterial, Anticandidal, MIC, Microbroth dilution, Ketoconazole

\section{INTRODUCTION}

Thanks to the improving investigations on development of new antibiotics, moderate human life period increasing significantly over time. Discovering new type of bacterial effecting molecules resulted altering several diseases including pneumonia, meningitis, septicemia etc. However, consuming excess amount of antibiotics increasing the bacterial resistance and lead to decreasing the number of bacteria killing molecules day by day [1-4]. Large number of antibiotics have at least one heterocycle like pyridine [5-7], furan [8-10], pyrrole [11, 12], pyrimidine [13, 14] etc. In medicinal chemistry, thiophene derivatives have been very well known for their therapeutic applications. Many thiophene derivatives have been developed as chemotherapeutic agents and are widely used. Thiophene nucleus is one of the most important heterocycles exhibiting remarkable pharmacological activities [15-17]. Molecules that have a part of thiophene ring can act antidepressant, anti-inflammatory, anticonvulsant and antiepileptic properties [18]. Also, the number of thiophene ring containing molecules found to be effective against several bacteria are rising and reported in literature day by day [19-22].

In this study, three new thiophene containing dimethyl-5-hydroxyisophtalate esters (Tetramethyl-5,5'((thiophene-2,5-dicarbonyl)bis(oxy))diisophthalate $\left(\mathrm{C}_{1}\right)$, dimethyl5-((thiophene-2-carbonyl)oxy) isophthalate $\left(\mathrm{C}_{2}\right)$, dimethyl 5-(2-(thiophen-2-yl)acetoxy)isophthalate) $\left(\mathrm{C}_{3}\right)$ was synthesized and characterized with several spectroscopic methods. The antibacterial effect of synthesized molecules are investigated on seven bacteria and four candida with microbroth dilution techniques. The cytotoxic effect of evaluated on healthy mouse fibroblast NIH3T3 cell line. 


\section{MATERIALS AND METHODS}

\subsection{Chemical}

All chemical were used without further purifications. HR-MS measurements were recorded on Schimadzu LCMS-IT-TOF spectrometer. ${ }^{1} \mathrm{H}-\mathrm{NMR}$ and ${ }^{13} \mathrm{C}-\mathrm{NMR}$ spectra were recorded on Bruker DPX FT spectrometer. FT-IR spectra were recorded with Perkin Elmer Spectrum 100 Spectrometer using $\mathrm{KBr}$ discs. Elemental analysis was carried out using Elementar Vario EL III microanalyzer device. Melting points were measured in a Stuart SMP-30 melting point apparatus.

\subsection{General Synthesis of Dimethyl-5-hydroxy Isophthalate Derivatives (Compound $C_{1}, C_{2}$ and $C_{3}$ )}

Three new thiophene esters synthesis procedure was depicted in Figure 1.

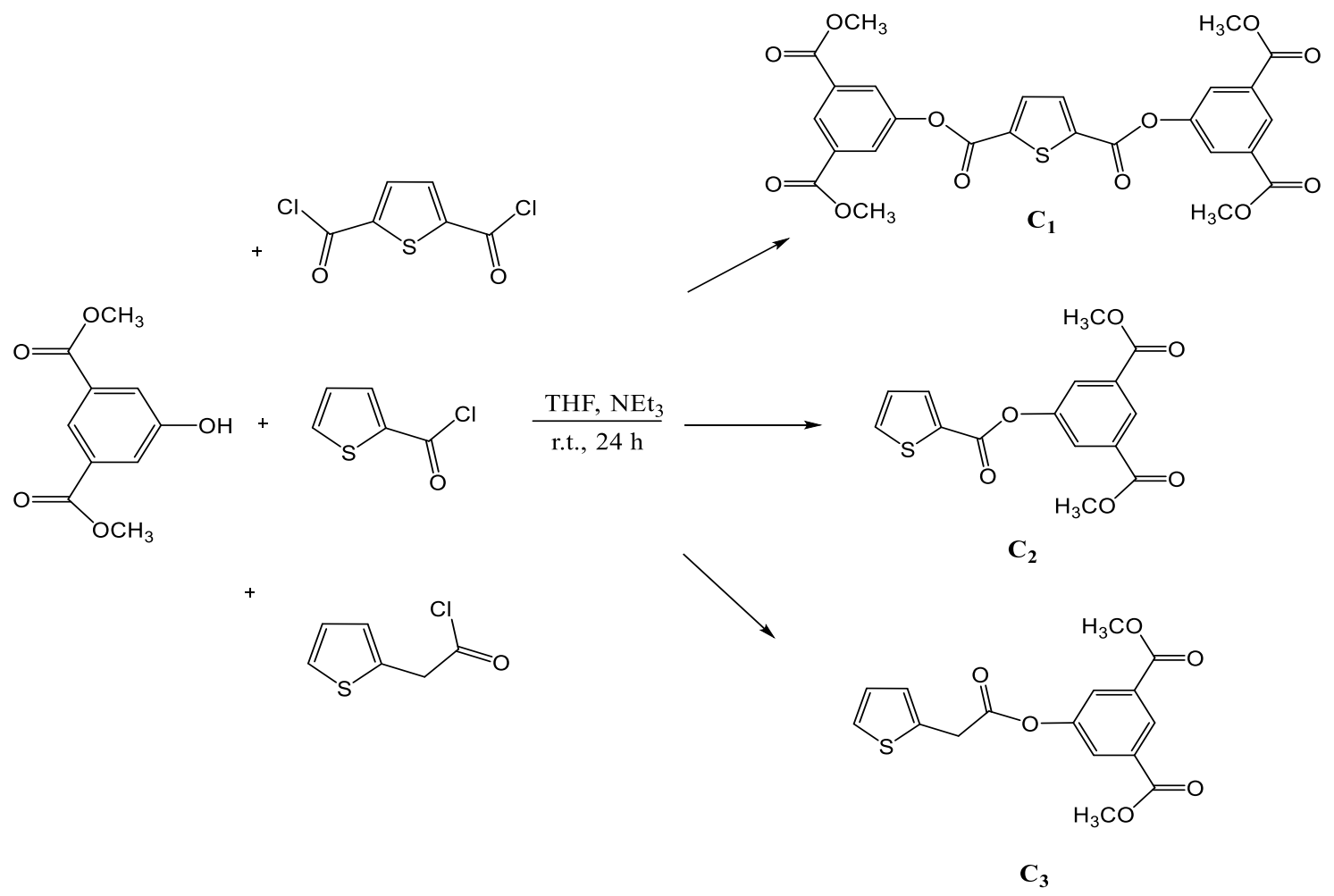

Figure 1: Synthesis procedure of three new dimethyl-5-hydroxy isophthalate esters.

\section{Tetramethyl 5,5'-((thiophene-2,5-dicarbonyl)bis(oxy)) diisophthalate $\left(\mathrm{C}_{1}\right)$}

Thiophene-2,5-dicarboxylic acid $(0.6 \mathrm{~g}, 0.0029 \mathrm{~mol}, 1 \mathrm{eq})$ was suspended in acetonitrile, then the solution was cooled in an ice bath to $0{ }^{\circ} \mathrm{C}$. Thionyl chloride $(0.63 \mathrm{~mL}, 0.0087 \mathrm{~mol}, 3 \mathrm{eq})$ was added dropwise to the first solution over $30 \mathrm{~min}$. Solution was kept at room temperature for $48 \mathrm{~h}$ and excess thionyl chloride and solvent was evaporated under reduced pressure. Oily residue was added dropwise directly to the dimethyl-5-hydroxyisophtalate $(0.8 \mathrm{~g}, 0,0038 \mathrm{~mol}, 1.3 \mathrm{eq})$ and triethylamine $\left(\mathrm{NEt}_{3}\right)(0.6$ $\mathrm{mL}, 0.0043 \mathrm{~mol}, 1.5 \mathrm{eq})$ solution in tetrahydrofuran (THF) and the reaction was checked with TLC certain time period. After completion of reaction, excess tetrahydrofuran was evaporated and the residue was poured into cold deionized water. The insoluble product precipitated immediately and filtrated over vacuum filtration, then washed three times with water. Light brown powder obtained (Compound C1). Yield: $52 \%$, m.p.: $190{ }^{\circ} \mathrm{C}$, Anal. Calc. (\%) for $\mathrm{C}_{26} \mathrm{H}_{20} \mathrm{O}_{12} \mathrm{~S}$ : $\mathrm{C}=56.1 ; \mathrm{H}=3.6 ; \mathrm{S}=5.7 ; \mathrm{O}=34.6$. Found: $\mathrm{C}=55.9 ; \mathrm{H}=3.8 ; \mathrm{S}=5.8 ; \mathrm{O}=34,5$. IR $\left(\mathrm{KBr}, \mathrm{cm}^{-1}\right): 3104.2 ; 1726.4 ; 1250.7 ; 1060.4 ; 751.6 .{ }^{1} \mathrm{H}-\mathrm{NMR}:(400$ 
$\left.\mathrm{MHz}, \mathrm{CDCl}_{3}, \delta \mathrm{ppm}\right): 8.62(\mathrm{~s}, 2 \mathrm{H}), 8.11(\mathrm{~s}, 4 \mathrm{H}), 8.05(\mathrm{~d}, \mathrm{~J}=3.6 \mathrm{~Hz}, 2 \mathrm{H}), 3.96(\mathrm{~s}, 12 \mathrm{H}) .{ }^{13} \mathrm{C}-\mathrm{NMR}:(400$ $\left.\mathrm{MHz}, \mathrm{CDCl}_{3}, \delta \mathrm{ppm}\right): 165.20,159.29,150.17,138.51,134.86,132.22,128.57,127.03,52.7 . \mathrm{MS}$ $[\mathrm{M}+\mathrm{Na}]^{+}: \mathrm{m} / z 579.05$

\section{Dimethyl 5-((thiophene-2-carbonyl)oxy)isophthalate $\left(\mathbf{C}_{2}\right)$}

Dimethyl-5-hydroxyisophtalate (1.28 g, $0.0061 \mathrm{~mol}, 1.3 \mathrm{eq})$ and triethylamine $(0.97 \mathrm{~mL}, 0.007 \mathrm{~mol}, 1.5$ eq) was dissolved in THF then, thiophene-2-carbonyl chloride $(0.5 \mathrm{~mL}, 0.0046 \mathrm{~mol}, 1 \mathrm{eq})$ was added dropwise to the first solution at $0{ }^{\circ} \mathrm{C}$. After $24 \mathrm{~h}$, excess solvent was evaporated and residue poured into cold water, insoluble product precipitated, filtrated, washed and dried under vacuum. White powder. Yield: $48 \%$, m.p: $133^{\circ} \mathrm{C}$, Anal. Calc. $(\%)$ for $\mathrm{C}_{15} \mathrm{H}_{12} \mathrm{O}_{6} \mathrm{~S}: \mathrm{C}=56.3 ; \mathrm{H}=3.8 ; \mathrm{O}=29.9 ; \mathrm{S}=10.1$. Found: $\mathrm{C}=56.1 ; \mathrm{H}=3.7 ; \mathrm{O}=30,1 ; \mathrm{S}=10.1$. IR $\left(\mathrm{KBr}, \mathrm{cm}^{-1}\right): 3106.2 ; 1728.2 ; 1250.2 ; 1064.7 ; 751.6 .{ }^{1} \mathrm{H}-\mathrm{NMR}:(400$ $\left.\mathrm{MHz}, \mathrm{CDCl}_{3}, \delta \mathrm{ppm}\right): 8.59(\mathrm{~s}, 1 \mathrm{H}), 8.08(\mathrm{~s}, 2 \mathrm{H}), 7.99(\mathrm{~d}, \mathrm{~J}=2.8, \mathrm{~Hz}, 1 \mathrm{H}), 7.69(\mathrm{~d}, \mathrm{~J}=4.4 \mathrm{~Hz}, 1 \mathrm{H}), 7.18$ (t, J=4.4 Hz, 1H), 3.94 (s, 6H). ${ }^{13} \mathrm{C}-\mathrm{NMR}:\left(400 \mathrm{MHz}, \mathrm{CDCl}_{3}, \delta \mathrm{ppm}\right): 165.34,160.08,150.54,135.25$, $134.19,132.03,131.92,128.22,128.19,127.27,52.60 . \mathrm{MS}[\mathrm{M}+\mathrm{Na}]^{+}: \mathrm{m} / z$ 343.02.

\section{Dimethyl 5-(2-(thiophen-2-yl)acetoxy)isophthalate $\left(C_{3}\right)$}

Compound $\mathrm{C}_{3}$ was synthesized according to the same procedure described above. Thiophene-2-acetyl chloride was used instead of thiophene-2-carbonyl chloride. White powder. Yield: $62 \%$, m.p.:51 ${ }^{\circ} \mathrm{C}$, Anal. Calc. (\%) for $\mathrm{C}_{16} \mathrm{H}_{14} \mathrm{O}_{6} \mathrm{~S}: \mathrm{C}=57.5 ; \mathrm{H}=4.2 ; \mathrm{O}=28.7 ; \mathrm{S}=9.6$. Found: $\mathrm{C}=57.3 ; \mathrm{H}=4.1 ; \mathrm{O}=29.2 ; \mathrm{S}=9.4$. IR $\left(\mathrm{KBr}, \mathrm{cm}^{-1}\right)$ : 3048.1; 1731.5; 1433.6; 1255.6; 1130.7; 764.9. ${ }^{1} \mathrm{H}-\mathrm{NMR}:\left(400 \mathrm{MHz}, \mathrm{CDCl}_{3}, \delta \mathrm{ppm}\right)$ : $8.34(\mathrm{~s}, 1 \mathrm{H}), 7.96(\mathrm{~s}, 2 \mathrm{H}), 7.44(\mathrm{~d}, \mathrm{~J}=5.2 \mathrm{~Hz}, 1 \mathrm{H}), 7.06(\mathrm{~s}, 1 \mathrm{H}), 6.99(\mathrm{t}, \mathrm{J}=4.4 \mathrm{~Hz}, 1 \mathrm{H}), 4.25(\mathrm{~s}, 2 \mathrm{H}), 3.87$ (s, 6H). ${ }^{13} \mathrm{C}-\mathrm{NMR}:\left(400 \mathrm{MHz}, \mathrm{CDCl}_{3}, \delta \mathrm{ppm}\right): 169.59,165.05,151.22,134.91,132.09,128.09,127.46$, $127.41,127.31,126.28,53.20,34.79$. MS $[\mathrm{M}+\mathrm{Na}]^{+}: \mathrm{m} / z 357.03$.

\section{Cytotoxicity}

Cytotoxicity Cytotoxicity tests were performed using the MTT assay. NIH/3T3 mouse embryonic fibroblast cell line (ATCC® CRL-1658 ${ }^{\mathrm{TM}}$ ) obtained from ATCC.

NIH/3T3 cells were incubated in Dulbecco's Modified Eagle's Medium (Hyclone, Thermo Scientific, USA) supplemented with fetal calf serum (Hyclone, Thermo Scientific, USA), $100 \mathrm{IU} / \mathrm{mL}$ penicillin and $100 \mathrm{mg} / \mathrm{mL}$ streptomycin (Hyclone, Thermo Scientific, USA) at $37^{\circ} \mathrm{C}$ in a humidified atmosphere of $95 \%$ air and $5 \% \mathrm{CO}_{2}$. NIH/3T3 cells were seeded at $5 \times 10^{3}$ cells into each well of 96 -well plates. After $24 \mathrm{~h}$ of incubation, the culture media were removed and compounds were added to culture medium in the range between 3.9 and $500 \mu \mathrm{M} / \mathrm{mL}$ concentrations. Then, cytotoxicity test was performed using the MTT assay, which measures mitochondrial activity, in NIH/3T3 cells. Firstly, $10 \mu \mathrm{L}$ MTT solution (5 $\mathrm{mg} / \mathrm{mL}$ MTT powder in PBS) was added and incubated for 3 hours at $37{ }^{\circ} \mathrm{C}, 5 \%$ dimethyl sulfoxide (DMSO) was added. OD values of each well was read at $540 \mathrm{~nm}$. Inhibition $\%$ was calculated for each concentration of the compounds according to the formula below [23] and IC50 values were estimated by plotting a dose-response curve of the inhibition \% versus concentration [24].

Inhibition $\%=100-\left[\left(\mathrm{OD}_{\text {test compound }}-\mathrm{OD}_{\text {blank }} / \mathrm{OD}_{\text {solvent control- }} \mathrm{OD}_{\text {blank }}\right)\right] \mathrm{x} 100$

\subsection{Antimicrobial Activity}

Antimicrobial activity of the final compounds was evaluated by the broth microdilution method according to the modified NCCLS M27-A2 standard procedure as indicated in the literature [25]. Tested microorganism strains and origins were as follows: Staphylococcus aureus (ATCC 25923); Enterococcus faecalis (ATCC 29212); Enterococcus faecalis (ATCC 51922); Klebsiella pneumoniae (ATCC 700603); Pseudomonas aeruginosa (ATCC 27853); Escherichia coli (ATCC 35218); 
Ünver and Cantürk / Anadolu Univ. J. of Sci. and Technology A - Appl. Sci. and Eng. 19(1)-2018

Escherichia coli (ATCC 25922); Candida albicans (ATCC 90028); Candida glabrata (ATCC 90030); Candida krusei (ATCC 6258); Candida parapsilosis (ATCC 22019). Further dilutions of the compounds and standard drugs in test medium were prepared at the required quantities of $800,400,200$, $100,50,25,12.5,6.25,3.13$ and $1.63 \mu \mathrm{M} / \mathrm{mL}$ concentrations with Mueller-Hinton broth and Sabouroud dextrose broth. Each experiment in the antimicrobial assays was replicated twice in order to define the MIC values. Ketoconazole and chloramphenicol were used as positive control and the results (MIC values) are shown in Table 1.

\section{RESULTS AND DISCUSSION}

\subsection{Characterization of Compounds}

The synthesis of stated compounds is given in Figure 1. Compounds $\mathrm{C}_{1}, \mathrm{C}_{2}$ and $\mathrm{C}_{3}$ were obtained from the esterification reaction between dimethyl-5-hydroxyisophtalate and thiophene-2,5-dicarboxylic acid (for $\mathrm{C}_{1}$ ), thiophene-2-carbonyl chloride (for $\mathrm{C}_{2}$ ) and thiophene-2-acetyl chloride (for $\mathrm{C}_{3}$ ) respectively. Spectroscopic values of synthesized compounds are given in materials and methods section. (see Supplementary Materials, Figure S1, S12)

In the FT-IR spectra of $\mathrm{C}_{1}, \mathrm{C}_{2}$ and $\mathrm{C}_{3}$ compounds, the carbonyl $(\mathrm{C}=\mathrm{O})$ group stretching vibration frequency was observed at $1726.4 \mathrm{~cm}^{-1}, 1728.2 \mathrm{~cm}^{-1}$ and $1731.5 \mathrm{~cm}^{-1}$ respectively. Ester bond C-O vibration peaks was observed between $1250.7 \mathrm{~cm}^{-1}-1060.4 \mathrm{~cm}^{-1}$ (for $\mathrm{C}_{1}$ ), $1250.2 \mathrm{~cm}^{-1}-1064.7 \mathrm{~cm}^{-1}$ (for $\mathrm{C}_{2}$ ) and $1255.6 \mathrm{~cm}^{-1}-1130.7 \mathrm{~cm}^{-1}$ (for $\mathrm{C}_{3}$ ). The C-S bond vibration frequency of thiophene ring was observed at $751.6 \mathrm{~cm}^{-1}, 751.6 \mathrm{~cm}^{-1}$ and $764.9 \mathrm{~cm}^{-1}$ for $\mathrm{C}_{1}, \mathrm{C}_{2}$ and $\mathrm{C}_{3}$ in the same order (see Supplementary Materials, Figure S1-S3).

In the ${ }^{1} \mathrm{H}-\mathrm{NMR}$ spectra of compound $1\left(\mathrm{C}_{1}\right)$, singlet signal observed at $3.96 \mathrm{ppm}$ is related to methyl ($\mathrm{CH}_{3}$ ) group of phthalate moiety. Same group signal was observed at $3.94 \mathrm{ppm}$ (for $\mathrm{C}_{2}$ ) and $3.87 \mathrm{ppm}$ for $\mathrm{C}_{3}$. Additionally, methylene (- $\mathrm{CH}_{2}-$ ) group of $\mathrm{C}_{3}$ was observed at $4.25 \mathrm{ppm}$ as expected. Aromatic proton peaks of both thiophene and phenyl ring can be seen between 8.62-8.05 ppm for $\mathrm{C}_{1}, 8.59-7.18 \mathrm{ppm}$ for $\mathrm{C}_{2}$ and 8.34-6.99 ppm for compound 3 as it should be. ${ }^{13} \mathrm{C}$-NMR signals of synthesized compounds were in agreement with proposed structures. Aliphatic carbon signals was observed at $52.7 \mathrm{ppm}$ for $\mathrm{C}_{1}, 52.6$ ppm for $\mathrm{C}_{2}$ and $53.2 \mathrm{ppm}$ for $\mathrm{C}_{3}$ compound. Additionally methylene $\left(-\mathrm{CH}_{2}-\right)$ group carbon signal was also observed at $34.7 \mathrm{ppm}$ for $\mathrm{C}_{3}$ (see Supplementary Materials, Figure S4-S9).

Compounds mass spectra are also support the proposed structures. The mass results are found to be, $m / z 579.05$ for $C_{1}, m / z, 343.02$ for $C_{2}$ and $m / z 357.03$ for $C_{3}$ as expected (see Supplementary Materials, Figure S10-S12).

\subsection{Antimicrobial and Cytotoxic Activity}

The cytotoxic activities of these compounds were evaluated against a normal mouse embryonic fibroblast cell line, $\mathrm{NIH} / 3 \mathrm{~T} 3$, for determining the selectivity of potential antimicrobial agents. According to MTT assays, this compound was identified as non-toxic $\left(\mathrm{IC}_{50}>500 \mu \mathrm{M} / \mathrm{mL}\right)$.

The antimicrobial activity was determined by minimal inhibitory concentration (MIC). Compounds $\left(\mathrm{C}_{1}\right.$, $\mathrm{C}_{2}$ and $\mathrm{C}_{3}$ ) were screened for their antibacterial and anticandidal activity (Table 1). Ketoconazole and chloramphenicol were used as positive control and the results (MIC values) are shown in Table 1. $\mathrm{C}_{2}$ was effective against $P$. aeruginosa when compared with chloramphenicol compounds $\mathrm{C}_{1}$ and $\mathrm{C}_{2}$ against Staphylococcus aureus, E. faecalis no activity. 
Ünver and Cantürk/Anadolu Univ. J. of Sci. and Technology A-Appl. Sci. and Eng. 19 (1)-2018

Table 1. Antibacterial activity data of compounds tested $(\mu \mathrm{M} / \mathrm{mL})$

\begin{tabular}{|c|c|c|c|c|c|}
\hline Microorganisms/Cell line & $\mathbf{C}_{1}$ & $\mathrm{C}_{2}$ & $\mathrm{C}_{3}$ & Chlor-amphenicol & Ketoconazole \\
\hline Staphylococcus aureus ATCC 25923 & 800 & 800 & 400 & 200 & ------ \\
\hline Pseudomonas aeruginosa ATCC 27853 & 200 & 200 & 200 & 200 & ------- \\
\hline Klebsiella pneumoniae ATCC 700603 & 400 & 200 & 200 & 50 & $\begin{array}{ll}------- \\
\end{array}$ \\
\hline E. faecalis ATCC 29212 & 800 & 800 & 200 & 50 & 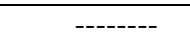 \\
\hline E. faecalis ATCC 51922 & 800 & 800 & 400 & 100 & $\begin{array}{ll}------- \\
\end{array}$ \\
\hline E. coli ATCC 35218 & 400 & 400 & 400 & 200 & -------- \\
\hline E. coli ATCC 25922 & 400 & 400 & 400 & 200 & 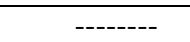 \\
\hline Candida albicans ATCC 90028 & 50 & 100 & 100 & ------- & 200 \\
\hline Candida glabrata ATCC 90030 & 100 & 200 & 100 & ------- & 200 \\
\hline Candida krusei ATCC 6258 & 100 & 100 & 100 & -------- & 3.125 \\
\hline Candida parapsilosis ATCC 22019 & 200 & 200 & 200 & -------- & 200 \\
\hline NIH/3T3 ATCC®CRL-1658 & $>500$ & $>500$ & $>500$ & $\begin{array}{ll}------- \\
\end{array}$ & -------- \\
\hline
\end{tabular}

\section{CONCLUSION}

The successful synthesis of three new thiophene derived dimethyl-5-hydroxyisophtalate esters has been reported. Synthesized compounds were tested for their antibacterial effects and compounds showed significal antibacterial activities. According to the literature, the presence of sulphur atom in a molecule lead to increasing the antibacterial activity [26]. Additionally, the positive charge of donor S atom in heteroaromatic ring lead to increasing the lipophilicity and give higher capability to penetrate the bacteria, so the presence of thiophene ring in the molecule lead to positive increase the antibacterial effect [27]. When compared with chloramphenicol ( $\mathrm{MIC}=200 \mu \mathrm{M} / \mathrm{mL}$ ), compounds, were the same effective compound against Pseudomonas aeruginosa ATCC 27853 with a MIC value of $200 \mu \mathrm{M} / \mathrm{mL}$. The other compounds and chloramphenicol showed the same level of activity against $E$. coli ATCC 35218. All compounds were found to be as active as ketoconazole against Candida parapsilosis ATCC 22019, whereas showed no significant anticandidal activity against Candida krusei ATCC 6258. Especially $\mathrm{C}_{1}$ most effective against Candida albicans (MIC=50 $\left.\mu \mathrm{M} / \mathrm{mL}\right)$ ATCC 90028. Comparatively, $\mathrm{C}_{1}$ four-fold effect than ketoconazole on Candida albicans ATCC 90028. The results indicated that, our findings are in agreement with literature and it can be said that thiophene containing molecules can possess antibacterial effect.

\section{CONFLICT OF INTEREST}

The author(s) confirm that this article content has no conflict of interest.

\section{ACKNOWLEDGEMENTS}

The authors thankfully acknowledge the Anadolu University, Chemistry Department for NMR analysis and Doping and Narcotic Matters Research Laboratory (DOPNA) for HR-Mass Measurements. 
Ünver and Cantürk/Anadolu Univ. J. of Sci. and Technology A-Appl. Sci. and Eng. 19 (1)-2018

\section{REFERENCES}

[1] Martinez JL, Baquero F, Andersson DI. Predicting Antibiotic Resistance, Nature Reviews Microbiology, 2007; 5, 958-965.

[2] Zhang QC, Lambert G, Liao D, Kim H, Robin K, Tung CK, Pourmand N, Austin RH. Acceleration of Emergence of Bacterial Antibiotic Resistance in Connected Microenvironments, Science, 2011; $333,1764-1767$.

[3] Høiby N, Bjarnsholt T, Givskov M, Molinc S, Ciofu O. Antibiotic resistance of bacterial biofilms, International Journal of Antimicrobial Agents, 2010; 35, 322-332.

[4] Andersson DI, Hughes D. Microbiological effects of sublethal levels of antibiotics, Nature Reviews Microbiology, 2014; 8,260-271.

[5] Jo YW, Im WB, Rhee JK, Shim MJ, Kimb WB and Choi EC. Synthesis and antibacterial activity of oxazolidinones containing pyridine substituted with heteroaromatic ring, Bioorganic \& Medicinal Chemistry, 2004; 12, 5909-5915.

[6] Raja R, Sivasubramaniyan A, Murugan, D, Subbaiah N, George J, Poovan S, Sangaraiah N, Alagusundaram P, Shanmugam K, Manivachagam C. A green synthesis of 1,2,3-triazolyl-pyridine hybrids and evaluation of their antibacterial activity, Res Chem Intermed, 2016; 42, 8005-8021.

[7] Elagamey AG, Sattar SA Taweel FE and Said S. An Efficient Synthesis and Antibacterial Activity of Pyrido[2,3-d] Pyrimidine, Chromeno[3,4-c] Pyridine, Pyridine, Pyrimido[2,3-c] Pyridazine, Enediamines, and Pyridazine Derivatives, J Heterocyclic Chem 2016; 53, 1801.

[8] Baharfar R, Asghari S, Rassi S, Mohseni M. Synthesis and evaluation of novel isatin and 5isatinylidenerhodanine-based furan derivatives as antibacterial agents, Res Chem Intermed 2015; 41, 6975-6984.

[9] Rani M, Yusuf M, Khan SA, Synthesis and in-vitro-antibacterial activity of [5-(furan-2-yl)phenyl]-4,5-carbothioamide-pyrazolines, Journal of Saudi Chemical Society, 2012; 16, 431-436.

[10] Jin YX, Zhong AG, Ge CH, Pan FY Yang JG, Wu Y, Xie M, Feng HW. A novel difunctional acylhydrazone with isoxazole and furan heterocycles: Syntheses, structure, spectroscopic properties, antibacterial activities and theoretical studies of (E)-N'-(furan-2-ylmethylene)-5methylisoxazole-4-carbohydrazide, Journal of Molecular Structure, 2012; 1010, 190-196.

[11] Balachandra B, Shanmugam S, Muneeswaran T and Ramakritinan M. Iodine catalyzed one-pot synthesis of highly substituted $\mathrm{N}$-methyl pyrroles via $[3+2]$ annulation and their in vitro evaluation as antibacterial agents, RSC Adv, 2015; 5, 64781.

[12] Joshi SD, More Y, Vagdevi HM, Vaidya VP, Gadaginamath GS, Kulkarni VH. Synthesis of new 4-(2,5-dimethylpyrrol-1-yl)/4-pyrrol-1-yl benzoic acid hydrazide analogs and some derived oxadiazole, triazole and pyrrole ring systems: a novel class of potential antibacterial, antifungal and antitubercular agents. Med Chem Res 2013; 22, 1073-1089.

[13] Kaping S, Boiss I, Singha LI, Helissey P, Vishwakarma JN. A facile, regioselective synthesis of novel 3-(N-phenylcarboxamide)pyrazolo[1,5-a]pyrimidine analogs in the presence of $\mathrm{KHSO}_{4}$ in aqueous media assisted by ultrasound and their antibacterial activities. Mol Divers, 2016; 20, 379390. 
[14] Verbitskiy EV, Baskakova SA, Rasputin NA, Gerasimova NA, Amineva PG, Evstigneeva NP, Zil'berberg NV, Kungurov NV, Kravchenko MA, Skornyakov SN, Rusinov GL, Chupakhin ON and Charushin VN. Microwave-assisted synthesis and evaluation of antibacterial activity of novel 6-fluoroaryl-[1,2,4]triazolo[1,5-a]pyrimidines, ARKIVOC, 2016; 5, 268-278.

[15] Mishra R, Jha KK, Kumar S, Tomer I. Synthesis, properties and biological activity of thiophene: A review, Der Pharma Chemica, 2011; 3(4), 38-54.

[16] Bush K, Pucci MJ. New antimicrobial agents on the horizon. Biochemical Pharmacology, 2011; 82 (11), 1528-1539.

[17] Altıntop D, Özdemir M, Atlı A, Kaplancıklı ZA, Synthesis and evaluation of new thiazole derivatives as potential antimicrobial agents. Letters in Drug Design and Discovery, 2016; 13(9), 903-911.

[18] Mabkhot YN, Kaal NA, Alterary S, Showiman S, Barakat A, Ghabbour HA and Frey W, Molecules, 2015; 20, 8712-8729.

[19] Kaya E, Turan N, Gündüz B, Çolak, N, Körkoca H. Synthesis, Characterization of Poly-2- (2hydroxybenzylideneamino)-6-phenyl-4,5,6,7-tetrahydrobenzo[b]thiophene-3-

carbonitrile:Investigation of Antibacterial Activity and Optical Properties, Polymer Engineering and Science, 2012; 52, 7, 1581-1589.

[20] Elsabee MZ, Ali EA, Mokhtar SM, Eweis M. Synthesis, characterization polymerization and antibacterial properties of novel thiophene substituted acrylamide, Reactive \& Functional Polymers, 2011; 71, 1187-1194.

[21] Wardakhan WW, Louca NA and Kamel MM. The Reaction of 2-Aminocyclohexeno[b]thiophene Derivatives with Ethoxycarbonyl isothiocyanate: Synthesis of Fused Thiophene Derivatives with Antibacterial and Antifungal Activities, Acta Chim Slov, 2007; 229, 54, 229-241.

[22] Zhao Q, Li J, Zhang X, Li Z and Tang Y. Cationic Oligo (thiophene ethynylene) with BroadSpectrum and High Antibacterial Efficiency under White Light and Specific Biocidal Activity against S. aureus in Dark, ACS Appl Mater Interfaces, 2016; 8, 1019-1024.

[23] Patel S, Gheewala N, Suthar A, Shah A. In-vitro cytotoxicity activity of Solanum nigrum extract against Hela cell line and Vero cell line. Int J Pharm Pharm Sci, 2009; 1(1), 38-46.

[24] Protopopova M, Hanrahan C, Nikonenko B, Samala R, Chen P, Gearhart J, Einck L, Nacy CA. Identification of a new antitubercular drug candidate, SQ109, from a combinatorial library of 1,2ethylenediamines. J Antimicrob Chemother, 2005; 56(5), 968-974.

[25] Clinical and Laboratory Standards Institute, Methods for Dilution Antimicrobial Susceptibility Tests for Bacteria That Grow Aerobically Approved Standard; Wayne, PA, USA, 2006.

[26] Eweis M, Elkholy S, Elsabee MS. Antifungal efficacy of chitosan and its thiourea derivatives upon the growth of some sugar-beet pathogens, Int J Biol Macromol, 2006; 38, 1-8.

[27] Gündüzalp AB, Özbek N and Karacan N. Synthesis, characterization, and antibacterial activity of the ligands including thiophene/furan ring systems and their $\mathrm{Cu}$ (II), $\mathrm{Zn}$ (II) complexes, Med Chem Res, 2012; 21, 3435-3444. 